\title{
Statutory audit in Slovakia - significant phenomenon of global European changes
}

\author{
Denisa Domaracká ${ }^{1, *}$, and Veronika Kn̆ažková2 \\ ${ }^{1}$ University of Economics in Bratislava, Department of Accounting and Auditing, Dolnozemská cesta \\ 1, 85235 Bratislava, Slovakia \\ ${ }^{2}$ University of Economics in Bratislava, Department of Accounting and Auditing, Dolnozemská cesta \\ 1, 85235 Bratislava, Slovakia
}

\begin{abstract}
The changing global economy environment also affected the area of statutory audit. Nowadays, statutory audit faces the significant changes not only because of the processes of digitization and automation in accounting and auditing, but because of increased and tightened legislative regulation, too. The most important aspects of financial reporting and auditing are subject to EU Regulations and EU Directives. For this reason, the issue of legislative regulation changes in field of statutory audit in Slovakia has become the subject of our article. Currently, the proposal of amending and supplementing Act. No 431/2002 Coll. on Accounting, as amended underwent an interdepartmental comment procedure. The proposal includes the changes on requirements for statutory audit. This article examines the current proposal to change (mainly increase) the conditions for performing the mandatory statutory audit of financial statements in Slovak audit environment. Our goal is to clarify the reasons and implications behind the changes of Slovak legislation as well as the impact of these changes on audit performance in Slovakia. We believe conducting statutory audits in accordance with the applicable legislation accepted and implemented at international European level can contribute to transparency and improve the quality of audit performance. In order to achieve the goal, it was necessary to choose a purposeful work methodology and research methods.
\end{abstract}

\section{Introduction}

In order to promote credible financial reporting processes across the EU, members of the body within an undertaking that is responsible for the preparation of the undertaking's financial statements should ensure that the financial information included in the undertaking's annual financial statement and the group's consolidated financial statement gives a true and fair view. The information presented in the financial statements is a base for potential users who make decisions according to them [1, 2, 3, 4]. It is because the information needs of each user group are different [5].

In this context, the audit of financial statements is a tool of ensuring that objective information is reported in the financial statements [6].

\footnotetext{
*Corresponding author: denisa.domaracka@euba.sk
} 
The primary objective of a statutory audit is currently to obtain an auditor's opinion whether the financial statements are prepared, in all material aspects, in accordance with the applicable financial reporting framework of the following entities:

- which are required to have financial statements audited;

- which have chosen to verify the financial statements voluntarily.

Statutory audit in Slovakia is required if the conditions according to article 19 (1) of Act. No. 431/2002 Coll. on Accounting, as amended (the "Act on Accounting") are met. In the current version of this Act, the scope of the auditor's obligation to audit the financial statements is adjusted as follows: "Regular (and extraordinary) individual financial statements is required to be audited of that entity:

a) which is a trading company (if compulsorily creates the registered capital) and

cooperative if at the date on which the financial statements are prepared and for the immediately preceding accounting period, they fulfilled at least two of the following conditions:

- the total amount of the assets exceeded 1000000 EUR,

- net turnover exceeded 2000000 EUR,

- the average number of employees in one accounting period exceeded 30.

b) which is a trading company and cooperative whose securities have been admitted to regulated market,

c) whose an obligation is stipulated by a special regulation,

d) which financial statements are prepared in accordance with article 17a of Act on

Accounting", i.e. according to International Financial Reporting Standards "IFRS".

Accounting entities in Slovakia prepare financial statements according Slovak legislation or IFRS [7].

In addition to the separate financial statements, the consolidated financial statements must be audited by a statutory auditor, without any conditions.

Legal entities whose annual share of the tax received is more than 35000 EUR for the accounting period in which the funds were used are also obligated to audit the financial statements.

The area of statutory audit - namely the above-mentioned limit conditions (referred to the point a) that are required for a statutory audit of the regular and extraordinary individual financial statements, together with the extension of the range of the entities which this obligation arises, were the proposed changes to the Act on Accounting.

\subsection{Upcoming changes in Slovak Act on Accounting for statutory audit}

In the draft amendment to the Act amending Act No. 431/2002 Coll. on Accounting, as amended (article 19 (1a)), the obligation to statutory audit of regular and extraordinary individual financial statements should be extended to cover limited partnerships and public companies. According to current wording of article 19 (1a) Act on Accounting, only a trading companies which compulsorily creates the registered capital (and cooperative) are obligated to have their regular and extraordinary individual financial statements audited.

In article 56 (1) Act No. 513/1991 Coll. commercial code, as amended, it states that the trading company is a public company, limited partnership, limited liability company, joint stock company and simple company for shares but the registered capital compulsorily creates only:

- limited liability company;

- joint stock company;

- simple company for shares. 
As a public company and limited partnership do not have to create the registered capital, it has not been required to have their financial statements audited even though they have fulfilled the limit conditions according to article 19 (1a) Act on Accounting.

In the draft amendment, after a responsible review of the limit conditions by the Slovak Ministry of Finance, there is a propose to increase the limit conditions (namely the total amount of the assets and net turnover) by $100 \%$ of the current limit conditions. It follows that an obligation of statutory audit of regular and extraordinary individual financial statements would arise from a trading company (irrespective of the capital requirement) and cooperative if at the date on which the financial statements are prepared and for the immediately preceding accounting period, they fulfilled at least two of the following conditions:

Table 1. Proposed limit conditions for statutory audit.

\begin{tabular}{|c|c|c|c|}
\hline Limit condition & Proposed & Current & \% Change \\
\hline Total amount of the assets exceeded & 2000000 EUR & 1000000 EUR & 100 \\
\hline Net turnover exceeded & 4000000 EUR & 2000000 EUR & 100 \\
\hline Average number of employees exceeded & 30 & 30 & - \\
\hline
\end{tabular}

In addition to these changes, auditors should also have an additional legal obligation. In accordance with article 17a (7) Act on Accounting, an entity preparing financial statements in accordance with "IFRS" is required to prepare a statement of the selected data from regular and extraordinary financial statements. The proposed change should require the statutory auditor to audit whether the selected data in the statement are consistent with the financial statements. The exemption from the audit of selected data applies to the entities under the supervision of the National Bank of Slovakia.

\section{Methodology}

Since 2004, Slovak republic has been included among the countries whose economy is regulated also by the system of supranational legislation and a statutory audit requirement exists also under EU law. The changes in accounting and auditing were part of a broader development of creating one institutional framework for an integrated EU financial market [8]. In the European Union (EU) and its member states the EU legislation is implemented [9].

However, EU members states have been given the option to exempt small entities from this requirement. Entities which are in Accounting Directive 2013/34/EU defined as small entities, they should not be subject to a statutory audit obligation based on EU legislation, as a statutory audit may also impose a significant administrative burden for this category of the entities. The discussion around small firms' audit has been very active during the last decade in countries like Finland and other Scandinavian countries [10].

Small entities according to Accounting Directive 2013/34/EU are defined as entities that at the date on which the financial statements are prepared do not exceed the limits of at least two of the following three conditions: total amount of the assets: 4000000 EUR; net turnover: 8000000 EUR; average number of employees during the accounting period: 50 . It should be noted that EU member states had the possibility to set limits in excess of the above-mentioned limits for total amount of the assets and net turnover, but these limits should not exceed 6000000 EUR for total amount of the assets and 12000000 EUR for net turnover. 
EU member states were obligated to adopt the Accounting Directive 2013/34/EU into their national legislation, and analyses suggest that by 2016 only 9 EU member states had used the option to exempt entities from the statutory audit obligation by increasing the limit conditions for the statutory audit obligation [11]. This was a clear demonstration of the fulfilment of the statutory audit obligation to act in the public interest. According to the International Federation of Accountants "IFAC", the primary way of protecting the public interest is compliance with the basic set of internationally recognised rules and standards as a means of ensuring the credibility of information for users [12].

On the other hand, EU legislation, i.e. Auditing Directive 2006/43/EC allows EU member states to perform a statutory audit also in small entities, considering the specific conditions and needs of small entities and users of their financial statements. If an EU member state requires a statutory audit of small entities, the measures may be established whereby the application of International Standards on Auditing "ISA" would be proportionate to the scale and complexity of the activities of such entities. Until 2016, only 1 EU member state took the possibility to reduce the limit conditions for statutory audit obligation. The results of the survey, following the implementation of the Accounting Directive, show no upward or downward trend in the limit conditions for statutory audit. [11]

It should not be forgotten that the development of the modern audit was accompanied mainly by the separation of economic and social realization of the ownership from the entity ownership, thus creating the need for a third party to carry out and independent audit. For many small entities, the same person is a shareholder as well as director and therefore they have a limited need of a third-party audit.

In particular, the size of small entities subject to statutory audit raises the questions about their impact on the statutory audit, which should be conducted in accordance with the principles of ISAs. The principles of ISAs, considering their applicability to the entities of all sizes, are designed primarily for medium and large entities. Global european usage and the acceptance of "ISAs" can increase not only the degree of confidence of users of the financial information presented in the financial statements, but also the uniform and transparent provision of assurance services [13].

\section{Results and Discussion}

When adopting EU legislation in national legislation, EU member states do not make use of the exemptions offered by EU legislation, and so it can may cause over-regulation, i.e. gold-plating.

If the draft amendment to the Act on Accounting is approved, Slovakia will also join the EU member states that have increased so far, the limit conditions for a statutory audit obligation. However, the proposed change in limit conditions for a statutory audit obligation in Slovakia caused a few discussions among the auditors and audit firms, as the number of entities that would be required by the amendment to the statutory audit obligation would thus be reduced.

Approximately 10000 mandatory statutory audits of individual financial statements (considering all the above requirements) and more than 1000 mandatory statutory audits of consolidated financial statements are performed annually in Slovakia. However, more that $30 \%$ of these audits are audits carried out within the public sector. Under the current limit conditions, defined in article 19 (1a), more than 5000 entities are subject to mandatory statutory audit. When these limit conditions are increased, the number of entities that have a statutory audit obligation by meeting these criteria can be expected to decrease by more than 2000 . 
Table 2. Impact of change in limit conditions on the number of audited entities.

\begin{tabular}{|c|c|c|c|c|}
\hline & $\begin{array}{c}\text { Total amount } \\
\text { of the assets } \\
\text { exceeded }\end{array}$ & $\begin{array}{c}\text { Net turnover } \\
\text { exceeded }\end{array}$ & $\begin{array}{c}\text { Approximate number of } \\
\text { audited entities according to } \\
\text { these conditions }\end{array}$ & $\begin{array}{c}\text { Decrease of } \\
\text { audited entities } \\
\text { in \% }\end{array}$ \\
\hline $\begin{array}{c}\text { Current } \\
\text { state }\end{array}$ & 1000000 & 2000000 & 5400 & $\mathrm{x}$ \\
\hline $\begin{array}{c}\text { Proposed } \\
\text { change }\end{array}$ & 2000000 & 4000000 & 3000 & $45 \%$ \\
\hline
\end{tabular}

The table below illustrates that the proposed change in limit conditions should concern approximately 2400 entities, which, according to Slovak Ministry of Finance, should reduce the cost of audit services by approximately 9 million EUR. It is important to note that the introduction of statutory audit for public companies and limited partnerships should, however, will increase the number of statutory audits.

\section{Conclusion}

Harmonization and standardization represent a principal feature of present globalization [14]. Striving for a global convergence in audit harmonization processes is the best solution for audit profession. As well as a comparability of financial statements and a constant need of ensuring transparency are caused by vast of changes constantly influencing economic practices in the relevant economic environment [15].

The proposed amendment to the Act on Accounting is a measure aimed at eliminating the identified unjustified regulatory burden on business entities. Indeed, the Accounting Directive requires minimum harmonization and leaves to the EU member state to adjust the limit conditions to best match the size of the economy and the entities in the country.

It is difficult to assess whether the applicable limit conditions for the statutory audit obligation are adequate, as the interests of several stakeholders meet here. One option is to compare it with the comparable EU member states, considering the Gross Domestic Product GDP indicator when selecting the comparable countries. Gross Domestic Product is the most comprehensive measure of the overall level in the country, by which the performance of the economy in most countries in the world is measured. According to the several opinions, increase the limit conditions could cause the reduction of the transparency or quality of the entity's financial statements as well as a deficit of information for users of financial statements.

In conclusion, changes in limit conditions for statutory audit will raise several issues and only the audit practise will show the real impact of this change.

\section{References}

1. P. Krišková, J. Užík, The going concern within the overall perspective of the auditor on the financial statements. Účetnictví a auditing v procesu světové harmonizace, 111-114 (2016)

2. K. Máziková, L. Ondrušová. Valuation of transaction between related parties and ethical behaviour on managers and investors. Ethics as an essential condition for sustainable economic development, 51 - 56 (2014)

3. A. Šlosárová, Analýza účtovnej závierky. Bratislava: Vydavatel’stvo Ekonóm, (2014) 
4. M. Tumpach, Medzinárodné štandardy na zostavenie účtovnej závierky IFRS/IAS. Bratislava: Iura Edition, (2006)

5. B. Parajka, Are information needs of financial entities served by financial statements in the Slovak Republic. Financial management of firms and financial institutions institutions: proceedings: 10th international scientific conference, 950 - 957 (2015)

6. P. Krišková, J. Užík, Professional scepticism in statutory audit under conditions of increasing requirement on the relevance of accounting information. Úćtovníctvo a auditorstvo v procese svetovej harmonizácie, 103 - 106 (2017)

7. Z. Kubaščíková, R. Pakšiová, Impact of accounting standards on the results of financial analysis. IFRS: global rules \& local use: proceeding of the 3nd International scientific conference, 150-155 (2015)

8. S. J. Maijoor, A. Vanstraelen, Research opportunities in auditing in the EU. Auditing: A Journal of Practice and Theory 31(1), 115 - 126 (2012)

9. Z. Juhászová, P. Markovič, D. Mokošová, Fair value and its importance for financial decision-making. IFRS: global rules \& local use: proceeding of the 2nd International scientific conference, 64-69 (2014)

10. H. Ojala, J. Collis, J. Kinnunen, L. Niemi, P. Troberg, The demand for voluntary audit in micro-companies: Evidence from Finland. International Journal of Auditing 20 (3), $267-277$ (2016)

11. IESBA, Audit exemption threshold in Europe (2016) Available at: https://www.accountancyeurope.eu/wp-content/uploads/1605_Audit_exemption thresholds update.pdf

12. L. Kareš, Is the modification of International auditing and assurance standards board (IAASB) increasing the audit quality? Účetnictví a auditing v procesu světové harmonizace, 77 - 78 (2016)

13. V. Kňažková, Application of professional judgement providing of assurance services with an emphasis on subjectivity review and subsequent evaluation of the future financial information. Účetnictví a auditing v procesu světové harmonizace, $100-104$ (2016)

14. M. Hladika, D. Mokošová, J. Molín, Comparison of national accounting framework the case of Croatia, Slovakia and Czechia. Economy of Easten Croatia - vision and growth: 6 th International scientific symposium, 1028 - 1044 (2017)

15. L. Kareš, V. Kňažková, L. Rybka, Will the identified improvements of auditor's report meet the requirements of users and provide them with the value, i.e. benefit that they seek? Strategic Management: International Journal of Strategic Management and Decision Support Systems in Strategic Management, 15 - 26 (2013) 